\title{
Improving the innovative development management of Zaporizhzhia region's industrial complex
}

\author{
Tetiana Pulina ${ }^{1}$, Nadiia Shmygol ${ }^{1, *}$, Oleksii Narivs'kyi ${ }^{1}$, Wtadysława Łuczka $^{2}$, and Yeugeniia Shmygol $^{3}$ \\ ${ }^{1}$ National University “Zaporizhzhia Polytechnic”, 64 Zhukovsky Str., Zaporizhzhia, 69600, Ukraine \\ ${ }^{2}$ University of Life Sciences in Poznań, 28 Polish Army Str., 60-637 Poznan, Poland \\ ${ }^{3}$ Warsaw University of Technology, 1 Politechniki Sq., 00-661 Warsaw, Poland
}

\begin{abstract}
The paper carries out the strategic analysis of innovative possibilities of Zaporizhzhia region's industrial complex and investigates the indicators of innovative activity of industrial complexes of Zaporizhzhia region and Ukraine by Harrington's generalized desirability function. The evaluation results prove the "good" ability and readiness of the industrial complex of Zaporizhzhia region and Ukraine to carry out effective innovation activities. However, according to the comparative assessment of the innovative activity of Zaporizhzhia region's industrial complex and Ukraine's one, Zaporizhzhia region's industrial complex is found to lag 9.2\% behind Ukraine's. A cluster development strategy is suggested to improve the innovative development management of Zaporizhzhia region's industrial complex.
\end{abstract}

\section{Introduction}

The modern model of sustainable development of the national economy as a whole and its regional components is based on the continuous conversion of modern achievements of scientific and technological progress into the latest technologies, quality goods and services. Therefore, the reproduction of productive forces and manufacturing relations at the regional level requires radical changes, both within the industrial complex of the region and its sub-complexes. These changes are determined by a combination of internal and external factors, namely innovative technological changes in the traditional real economy. Therefore, special attention is paid to defining strategic directions of innovative development of Zaporizhzhia region's industrial complex by assessing enterprises' innovative activity in the industrial complex. Cluster development models are used to improve the innovative development management of industrial complexes in most industrialized countries.

In this context, it is of particular importance to define long-term strategic directions of innovative development of the region's industrial complex.

Issues of innovative development of the regions are reflected in the works [1-23].

The conducted research offers basic guidelines for assessing the development of the industrial complex of the region, as well as develops scientific approaches and recommendations for the management of the region's industrial complex. However, in general, the problem of defining strategic directions of innovative development of the region's industrial complex remains open; moreover, the lack of innovative development strategy of the industrial

*e-mail: nadezdash@ua.fm complex slows down the development of projects, programs and scenarios of socio-economic development.

The purpose of the paper is to improve the innovative development management of Zaporizhzhia region's industrial complex.

The following methods of economic research were used in the research process: abstract-logical (for theoretical generalizations and formulation of conclusions), statistical-economic (diagnostics of the state and assessment of innovative development of the region's industrial complex).

\section{The industrial potential of Zaporizhzhia region}

Zaporizhzhia region is one of the most economically attractive regions of Ukraine due to great industrial and agricultural potential, natural, as well as own energy resources, high scientific and technical potential, developed transport infrastructure, developed banking system and accessibility to the markets of Ukraine, CIS, Europe and Asia. There are more than 160 powerful industrial enterprises in the region. States, particularly by the exchange of good practices [9].

The industrial complex of the region provides $8.2 \%$ of the national volume of sold industrial products (UAH 202.3 billion in 2019) - this is the 4th place among the regions (table 1).

The development of the region's industrial complex is a required condition to achieve long-term competitive advantages and, accordingly, the effective operation of enterprises in the long run.

Most enterprises in the region need implementing effective modern energy-saving production technologies, as 
Table 1. The volume of sold industrial products by individual regions in 2019 [24]

\begin{tabular}{ccc}
\hline \multirow{2}{*}{ Territory } & \multicolumn{2}{c}{$\begin{array}{c}\text { Volume of sold } \\
\text { industrial products } \\
\text { in 2019 }\end{array}$} \\
\cline { 2 - 3 } & \multicolumn{2}{c}{$\begin{array}{c}\text { \% to total } \\
\text { production } \\
\text { sold }\end{array}$} \\
\hline UAH mln. & 100.0 \\
\hline Ukraine & 2480804.2 & 18.3 \\
Dnipropetrovsk & 454124 & 11.4 \\
region & 283946 & 9.4 \\
Donetsk region & 232979.5 & 8.2 \\
Kyiv (city) & 202366.2 & 7.5 \\
Zaporizhzhia region & 185639.2 & 45.19 \\
Kharkiv region & 1118842.7 & \\
Others & & \\
\hline
\end{tabular}

well as introducing effective measures to support domestic producers in the local market, by creating regional clusters in promising areas of the region's development [25].

The basis of the region's industrial complex is metallurgical and energy complexes which produce $23.1 \%$ of total iron, $34.3 \%$ of steel, $8.9 \%$ of coke, $25.9 \%$ of electricity in Ukraine [24].

In the industrial complex, the leading place is occupied by metallurgy $(35.7 \%)$, the second place in the structure of industry belongs to the power industry $(24.2 \%)$, in the third place is mechanical engineering (11.4\%) [26].

The industrial potential of Zaporizhzhia region is strengthened by a large number of branch scientific, research and designing institutes, which are fully capable of promoting the state policy of creating a strong industrial base that not only meets domestic needs, but is productively competitive on the world market

Recently, science, technology and innovation have become increasingly important for the economic development of both the region and the state as a whole, which provide a basis for effective development by generating new knowledge. It is innovation that becomes a prerequisite to create additional wealth and form the socioeconomic paradigm of modern society.

In 2019, the region is not among the leading ones in terms of innovation processes activity, although this indicator is still higher than its average Ukrainian value. In 2019, the region ranked 4th among the regions of Ukraine in terms of the share of innovatively active enterprises, while in 2013 it was the leader of innovative activity in Ukraine and took the 1st place.

In recent years, in the region there has been a tendency to reduce the number of innovative enterprises (figure 1) [26].

Thus, in 2019 in Zaporizhzhia region, 47 enterprises and organizations of the region were engaged in innovation activities, or $19.36 \%$ of the total number of surveyed against 49 enterprises in 2015 and 56 in 1995. 30 enterprises $(63.8 \%$ of total number of innovation- active enterprises) within the framework of innovation activities were engaged in purchasing equipment, 11 innovation-active

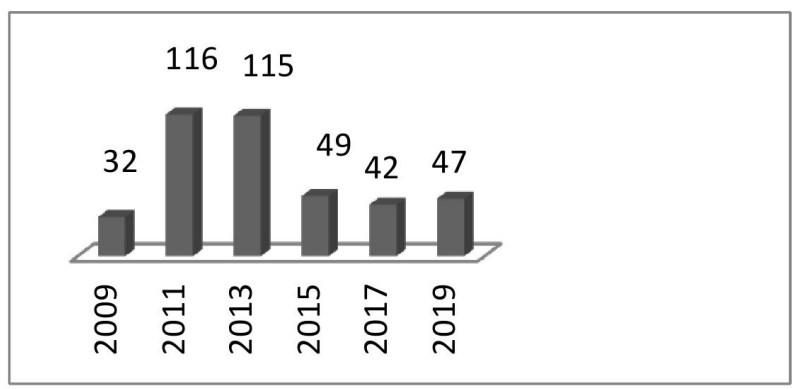

Figure 1. Number of enterprises and organizations that carry out scientific research and development

enterprises $(23.4 \%)$ conducted their own internal research and development and only 5 enterprises (12.8\%) were engaged in market innovation [26]. The number of industrial enterprises that have implemented innovations is given in table 2 . The predominant number of innovation-active en-

Table 2. Number of industrial enterprises that implemented innovations

\begin{tabular}{|c|c|c|c|c|}
\hline Year & 2010 & 2015 & 2017 & 2019 \\
\hline Total, units & 19 & 45 & 37 & 43 \\
\hline implemented new & & & & \\
\hline technological & 11 & 20 & 21 & 32 \\
\hline processes, units & & & & \\
\hline $\begin{array}{l}\text { per cent to the total } \\
\text { number of companies }\end{array}$ & 57.9 & 44.4 & 56.8 & 74.4 \\
\hline implementing innovation & & & & \\
\hline $\begin{array}{l}\text { including low-waste, } \\
\text { resource-saving } \\
\text { and waste-free }\end{array}$ & 6 & 11 & 7 & 8 \\
\hline companies, units & & & & \\
\hline $\begin{array}{l}\text { per cent to the total } \\
\text { number of enterprises, } \\
\text { mastered the production }\end{array}$ & 31.6 & 24.4 & 18.9 & 18.6 \\
\hline of innovative & 14 & 35 & 26 & 21 \\
\hline $\begin{array}{l}\text { types of products, units } \\
\text { per cent to the total }\end{array}$ & & & & \\
\hline $\begin{array}{l}\text { number of companies } \\
\text { implementing innovation }\end{array}$ & 73.7 & 77.8 & 70.3 & 48.8 \\
\hline $\begin{array}{l}\text { - incl. types of } \\
\text { equipment, units }\end{array}$ & 3 & 21 & 16 & 13 \\
\hline $\begin{array}{l}\text { per cent to the total } \\
\text { number of companies }\end{array}$ & 15.8 & 46.7 & 43.2 & 30.2 \\
\hline implementing innovation & & & & \\
\hline $\begin{array}{l}\text { sold innovative } \\
\text { production, units }\end{array}$ & 18 & 42 & 31 & 25 \\
\hline $\begin{array}{l}\text { per cent to the total } \\
\text { number of companies } \\
\text { implementing innovation }\end{array}$ & 94.7 & 93.3 & 83.8 & 58.1 \\
\hline
\end{tabular}

terprises of Zaporizhzhia region is concentrated in the regional center - Zaporizhzhia (more than 90\%), the second and third places in the number of innovation-active enterprises are occupied by Berdyansk and Melitopol. 


\section{The main type of innovative activity of industrial enterprises}

The main type of innovative activity of industrial enterprises in 2019 and so forth continues to be the development of innovative products manufacturing. 21 enterprises, or $48.8 \%$ of the total number of industrial enterprises that implemented innovations, are engaged in such activities. In 2013, there were 44 such enterprises. 32 enterprises introduced new technological processes (compared to 35 in 2013), but only every 3rd of these enterprises implemented resource-saving and waste-free technologies. The volume of sold innovative products decreased from UAH 3,162.3 mln. in 2017 to UAH 2,801.82 mln. in 2019 , or by $11.4 \%$. In terms of the volume of sold innovative products, the region in 2019 ranked 8th in Ukraine. The region accounted for $8.2 \%$ of the total volume of sold innovative products in Ukraine.

The volume of fundamentally new innovative products also remains insignificant. Industrial enterprises prove to sell innovative new products primarily for enterprises, not for the market.

The decrease in the output of innovative products in the region is largely due to innovation costs reduction. Thus, during 2017-2019 in the region the innovation activities costs were reduced from UAH 1,393.4 mln. to UAH 681.7 mln., or by 2.1 times. In 2019, the region ranked 9th in the total innovation funding in Ukraine. It accounted for $4.8 \%$ of its total volume.

Regarding the structure of innovation funding sources, in 2019, as in previous years, the key ones are the enterprises' own funds $(98.05 \%)$. A number of large-scale innovative projects have been implemented at the region's enterprises, which are aimed at ecological and energyefficient renovation, modernization of production and development of new types of products. The main innovation funding source over the past ten years are the enterprises' own funds (table 3 ).

Table 3. The industrial enterprises' innovation funding sources

\begin{tabular}{|c|c|c|c|c|c|}
\hline \multirow[t]{2}{*}{ Year } & \multirow[t]{2}{*}{$\begin{array}{l}\text { Total } \\
\text { costs }\end{array}$} & \multicolumn{4}{|c|}{$\begin{array}{l}\text { Incl. at the } \\
\text { expense } \\
\text { of funds, } \\
\text { UAH thous. }\end{array}$} \\
\hline & & $\begin{array}{l}\text { Own } \\
\text { funds }\end{array}$ & $\begin{array}{l}\text { Domestic } \\
\text { investors }\end{array}$ & $\begin{array}{l}\text { Foreign } \\
\text { investors }\end{array}$ & $\begin{array}{c}\text { Other } \\
\text { sources }\end{array}$ \\
\hline$\overline{2009}$ & 163878.0 & 160788.5 & - & - & 623.8 \\
\hline 2010 & 128595.1 & 127895.1 & - & - & - \\
\hline 2011 & 800427.2 & 648835.4 & 12682.5 & 9463.5 & 130331.2 \\
\hline 2012 & 242990.6 & 235426.2 & - & - & 6459.4 \\
\hline 2013 & 298671.5 & 298667.5 & - & - & 4.0 \\
\hline 2014 & 339943.9 & 335729.6 & - & - & 4214.3 \\
\hline 2015 & 321051.3 & 321051.3 & - & - & - \\
\hline 2017 & 1393360.2 & 1161569.9 & - & - & 231790.3 \\
\hline 2019 & 681707.2 & 668400.3 & - & 3200 & 3400 \\
\hline
\end{tabular}

The main direction of innovation expenditures during 2009-2019 in the region is still the purchase of machinery, equipment and software. In 2019, expenditures in this area of innovation amounted to UAH $514.4 \mathrm{mln}$., which was $75.5 \%$ of the total expenditures on innovation. Industrial enterprises spent the least on acquiring other external knowledge. In 2019, it amounted to UAH $0.3 \mathrm{mln}$., which is only $4.54 \%$ of the total innovation costs. Expenditures on purchasing machinery, equipment and software increased the most during this period.

It should be noted that most powerful industrial enterprises that are the main consumers of innovative products have their own research institutions or cooperate with leading industry research institutions of Ukraine which compete significantly with private innovative firms.

Due to the high cost of research and development (R\&D) and designing, some companies refuse to develop and implement innovative products of their own production, explaining this by decrease in their competitiveness and insufficient financial support from the state.

Taking into account that there is an active market for innovation both within the country and abroad, in the region in most cases there is no mechanism of interaction between consumers and manufacturers of innovative products. The reason for this situation is the lack of an organizational system in the region, which allows to purposefully transform the results of scientific and technical activities into existing technologies and new enterprises that produce unique, competitive products on the world market.

Zaporizhzhia region has a very high innovation potential. However, in recent years, innovation and investment activities of the region's enterprises have not been developing effectively enough, despite the significant attention of the state to this field.

\section{The integral indicators for assessing the innovative development of Zaporizhzhia region's industrial complex}

To outline the innovation strategy of the region's industrial complex, it is necessary to determine the factors influencing the innovative development of Zaporizhzhia region's industrial complex and evaluate its innovative activity. To define the favorable and problematic factors influencing innovative development, it is relevant to evaluate the innovative activity of Zaporizhzhia region's industrial enterprises according to the methods proposed by O. B. Zhykhor and L. M. Matrosova [27, 28]. Data to calculate a comprehensive indicator of innovative development of Zaporizhzhia region's industrial complex are given in (table 4) [26].

Data to calculate a comprehensive indicator of innovative development of Ukraine industrial complex in 20092019 (table 5) [24].

To calculate innovative development indicators of $\mathrm{Za}$ porizhzhia region's industrial complex in 2009-2019 and innovative development indicators of Ukraine's industrial complex in 2009-2019, there are such evaluation criteria:

1. The breadth of coverage of the region's enterprises with innovative activities: 
Table 4. Data to calculate a comprehensive indicator of innovative development of Zaporizhzhia region's industrial complex in 2009-2019

\begin{tabular}{|c|c|c|c|c|c|c|c|c|c|}
\hline \multirow{2}{*}{$\begin{array}{l}\text { Output } \\
\text { data }\end{array}$} & \multicolumn{9}{|c|}{ Years } \\
\hline & 2009 & 2010 & 2011 & 2012 & 2013 & 2014 & 2015 & 2017 & 2019 \\
\hline $\begin{array}{c}\text { Number of IAE } \\
N_{i a}\end{array}$ & 31 & 22 & 116 & 115 & 115 & 108 & 49 & 42 & 47 \\
\hline $\begin{array}{c}\text { Number of } \\
\text { surveyed } \\
\text { enterprises } \\
(N)\end{array}$ & 441 & 415 & 421 & 386 & 399 & 470 & 403 & 384 & 397 \\
\hline $\begin{array}{l}\text { Volumes of sold } \\
\text { products }\end{array}$ & & & & & & & & & \\
\hline $\begin{array}{c}\text { UAH mln. } \\
\text { (in actual } \\
\text { prices), } \\
\text { UAH mln. } \\
\left(Q_{z}\right)\end{array}$ & 53095.4 & 66768 & 81503.2 & 82505.7 & 78490 & 97797.6 & 124249.8 & 197495.3 & 202366.2 \\
\hline $\begin{array}{c}\text { Manufacturing } \\
\text { of new products } \\
\text { types mastered, } \\
\text { articles }\left(r_{3} \text { vid }\right) \\
\text { New }\end{array}$ & 132 & 114 & 619 & 446 & 397 & 611 & 397 & 319 & 209 \\
\hline $\begin{array}{c}\text { technological } \\
\text { processes } \\
\text { implemented } \\
\left(H_{m}\right)\end{array}$ & 134 & 170 & 509 & 114 & 207 & 212 & 114 & 142 & 156 \\
\hline $\begin{array}{c}\text { Total amount } \\
\text { of innovation } \\
\text { costs, } \\
\text { UAH mln. } \\
\left(D_{o b}\right)\end{array}$ & 163.88 & 128.6 & 800.4 & 243 & 298.7 & 339.9 & 321.1 & 1393.4 & 681.7 \\
\hline $\begin{array}{l}\text { Number of } \\
\text { employees by } \\
\text { industrial } \\
\text { activity type, } \\
\text { thous. people } \\
(P)\end{array}$ & 176.5 & 175 & 173.6 & 170 & 163.1 & 151.2 & 149.6 & 138.8 & 137.3 \\
\hline $\begin{array}{c}\text { Volume of } \\
\text { shipped } \\
\text { innovative } \\
\text { products, } \\
\text { UAH mln. } \\
\left(V_{n}\right)\end{array}$ & 2144.9 & 1979 & 2490.3 & 1671.6 & 1671.1 & 1530 & 3162.3 & 4041.2 & 2801.8 \\
\hline
\end{tabular}

- Share of IAE in their total number, \% $\left(N_{i a} / N \cdot 100 \%\right)$;

- Share of shipped innovative products in total industrial output, $\%\left(V_{z} / Q_{z} \cdot 100 \%\right)$;

2. The range of distribution of types and objects of innovation among innovation-active enterprises:

- Average number of new types of industrial products per IAE $\left(r_{3 \text { vid }} / N_{i a}\right)$;

- Average number of new technologies per IAE $\left(H_{m} / N_{i a}\right)$.

3. The degree of financial support for innovation activities of enterprises involved in developing and implementing innovations:
- Average amount of innovation costs per one innovatively active enterprise, thous. UAH $\left(D_{o b} / N_{i a}\right)$;

- Average number of employees per IAE $\left(P / N_{i a}\right)$.

Economic and mathematical modeling based on a generalized desirability function (or Harrington's scale) was used to determine the complex indicator of innovative development of the industrial complex.

It should be noted that the integrated indicator of innovative development of machine-building enterprises based on the Harrington function varies in the range $\{0 ; 1\}$. Moreover, the closer it is to the unit, the greater the level of machine-building enterprises' innovative development is.

In general, the values of the Harrington function are interpreted as follows (table 6). 
Table 5. Indicators of innovative development of Ukraine's industrial complex of Ukraine in 2009-2019

\begin{tabular}{|c|c|c|c|c|c|c|c|c|c|}
\hline \multirow{2}{*}{$\begin{array}{l}\text { Output } \\
\text { data }\end{array}$} & \multicolumn{9}{|c|}{ Years } \\
\hline & 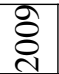 & $\begin{array}{l}0 \\
\text { o. } \\
\end{array}$ & $\vec{i}$ & 항 & m & $\stackrel{+}{\dot{i}}$ & 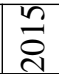 & $\bar{i}$ & 产 \\
\hline $\begin{array}{l}\text { Number of IAE } \\
\qquad N_{i a}\end{array}$ & $\Xi$ & 守 & $\begin{array}{l}0 \\
\infty \\
\infty\end{array}$ & $\stackrel{\infty}{\stackrel{\infty}{\Sigma}}$ & $\frac{n}{n}$ & 8 & 点 & $\frac{8}{6}$ & $\widehat{\infty}$ \\
\hline $\begin{array}{c}\text { Number of } \\
\text { surveyed } \\
\text { enterprises } \\
(N)\end{array}$ & $\stackrel{\widetilde{\delta}}{=}$ & 咅 & $\stackrel{+}{\stackrel{+}{+}}$ & 㝘 & 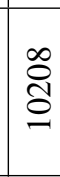 & $\stackrel{\circ}{\circ}$ & ఠิ & $\stackrel{\infty}{\stackrel{\infty}{a}}$ & के \\
\hline $\begin{array}{l}\text { Volumes of sold } \\
\text { products } \\
\text { UAH mln. } \\
\text { (in actual } \\
\text { prices), } \\
\text { UAH mln. } \\
\left(Q_{z}\right)\end{array}$ & $\begin{array}{l}0 \\
\dot{0} \\
n \\
b \\
0 \\
\infty\end{array}$ & $\begin{array}{l}\vec{n} \\
\infty \\
0 \\
0 \\
0\end{array}$ & $\begin{array}{l}0 \\
\infty \\
\infty \\
\infty \\
\infty \\
\infty\end{array}$ & 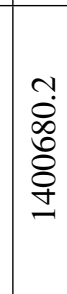 & $\begin{array}{l}\overrightarrow{0} \\
\text { m } \\
\text { m } \\
\text { ñ }\end{array}$ & 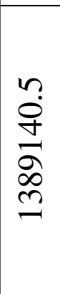 & 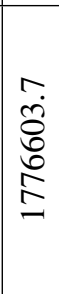 & 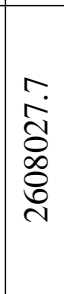 & $\begin{array}{l}\infty \\
0 \\
\infty \\
\infty \\
\infty \\
\check{\lambda} \\
\check{\lambda}\end{array}$ \\
\hline $\begin{array}{l}\text { Manufacturing } \\
\text { of new products } \\
\text { types mastered, } \\
\text { articles }\left(r_{3} \text { vid }\right)\end{array}$ & 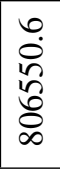 & $\begin{array}{l}\vec{\sigma} \\
\infty \\
\tilde{\delta} \\
\varnothing\end{array}$ & $\begin{array}{l}0 \\
\infty \\
\infty \\
\infty \\
\infty \\
\infty\end{array}$ & 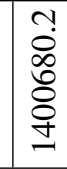 & $\begin{array}{l}\overrightarrow{0} \\
m \\
\dot{m} \\
\tilde{n} \\
=\end{array}$ & 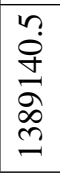 & 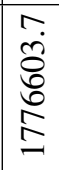 & $\begin{array}{l}r \\
\hat{i} \\
\delta \\
\infty \\
0 \\
d\end{array}$ & $\begin{array}{l}\infty \\
0 \\
\infty \\
\infty \\
\infty \\
\check{\sim} \\
\check{\sim}\end{array}$ \\
\hline $\begin{array}{c}\text { New } \\
\text { technological } \\
\text { processes } \\
\text { implemented } \\
\left(H_{m}\right)\end{array}$ & $\stackrel{\text { }}{\infty}$ & 空 & $\frac{0}{\sqrt[n]{4}}$ & $\stackrel{\infty}{\infty}$ & $\stackrel{0}{2}$ & $\stackrel{\stackrel{m}{I}}{I}$ & $\stackrel{\Xi}{\beth}$ & $\stackrel{\widetilde{\infty}}{\infty}$ & $\frac{\infty}{\approx}$ \\
\hline $\begin{array}{c}\text { Total amount } \\
\text { of innovation } \\
\text { costs, } \\
\text { UAH mln. } \\
\left(D_{o b}\right)\end{array}$ & $\begin{array}{l}\stackrel{a}{a} \\
\frac{\partial}{2}\end{array}$ & 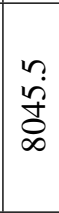 & $\begin{array}{l}\stackrel{\vartheta}{\tilde{g}} \\
\stackrel{\tilde{J}}{ }\end{array}$ & $\begin{array}{l}0 \\
\stackrel{0}{\infty} \\
\stackrel{\infty}{ \pm}\end{array}$ & 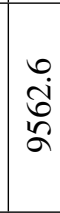 & $\begin{array}{l}\stackrel{a}{2} \\
\hat{\sigma}\end{array}$ & $\begin{array}{l}\vec{m} \\
\stackrel{\infty}{n} \\
\stackrel{n}{n}\end{array}$ & $\frac{n}{\Xi}$ & 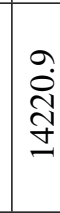 \\
\hline $\begin{array}{l}\text { Number of } \\
\text { employees by } \\
\text { industrial } \\
\text { activity type, } \\
\text { thous. people } \\
(P)\end{array}$ & ల్ల & $\begin{array}{l}8 \\
\mathbb{8} \\
\text { in }\end{array}$ & $\begin{array}{l}\infty \\
\mathbb{N} \\
\sim \\
\sim\end{array}$ & $\begin{array}{l}\mathbb{D} \\
\underset{\sim}{\sim}\end{array}$ & $\hat{\tilde{\delta}}$ & ลิ & 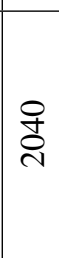 & $\stackrel{+}{\infty}$ & $\underset{8}{\varnothing}$ \\
\hline $\begin{array}{c}\text { Volume of } \\
\text { shipped } \\
\text { innovative } \\
\text { products, } \\
\text { UAH mln. } \\
\left(V_{n}\right)\end{array}$ & $\begin{array}{l}\stackrel{m}{v} \\
\stackrel{\tilde{m}}{m}\end{array}$ & 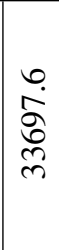 & 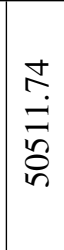 & 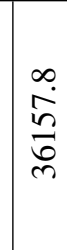 & $\begin{array}{l}0 \\
\dot{\sigma} \\
\infty \\
\tilde{m} \\
m\end{array}$ & 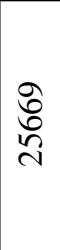 & ڤి & $\underset{\stackrel{\sim}{+}}{\stackrel{\sim}{\Sigma}}$ & 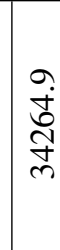 \\
\hline
\end{tabular}

The basis of this indicator is the idea of transforming the natural values of each innovation development indicator (table 7) into a dimensionless form in (table 8), followed by the definition of partial $i$ functions by Harrington's scale $d_{r i}$ (table 9) and a comprehensive indicator of innovative development of the region's industrial complex $D$ (table 10) and Ukraine's (table 11):

$$
D=\sqrt[r]{\prod_{i=1}^{r} d_{r_{i}},} \quad d_{r_{i}}=\exp \left(-\exp \left(-y_{r_{i}}\right)\right)
$$

where $r$ - the number of indicators used to assess innovation development; $d_{r_{i}}-$ a partial function by Harrington's
Table 6. Interpretation of estimates of the complex level of machine-building enterprises' innovative development based on the Harrington function

\begin{tabular}{|c|c|c|}
\hline № & $\begin{array}{l}\text { Values of the integrated } \\
\text { indicator of machine- } \\
\text { building enterprises' } \\
\text { innovative development } \\
\text { on the scale of the } \\
\text { desirability function }\end{array}$ & $\begin{array}{l}\text { Interpretation of the level of } \\
\text { machine-building enterprises' } \\
\text { innovative development }\end{array}$ \\
\hline 1 & $D>0.8$ & $\begin{array}{c}\text { High level of innovative } \\
\text { development }\end{array}$ \\
\hline 2 & $0.63<D<0.8$ & $\begin{array}{c}\text { Good level of innovative } \\
\text { development }\end{array}$ \\
\hline 3 & $0.37<D<0.63$ & $\begin{array}{c}\text { Satisfactory level of } \\
\text { innovative development }\end{array}$ \\
\hline 4 & $0.2<D<0.37$ & $\begin{array}{l}\text { Unsatisfactory level of } \\
\text { innovative development }\end{array}$ \\
\hline 5 & $D<0.2$ & $\begin{array}{c}\text { Low level of innovative } \\
\text { development }\end{array}$ \\
\hline
\end{tabular}

scale; $y_{r_{i}}-$ an innovation development indicator in a dimensionless form.

Table 7. Natural values of indicators of enterprises' innovative development of the region's industrial complex

\begin{tabular}{ccccccc}
\hline Year & $\begin{array}{c}r_{1}, \\
\%\end{array}$ & $\begin{array}{c}r_{2}, \\
\%\end{array}$ & $\begin{array}{c}r_{3}, \\
\text { units }\end{array}$ & $\begin{array}{c}r_{4}, \\
\text { units }\end{array}$ & $\begin{array}{c}r_{5}, \\
\text { UAH } \\
\text { thous. }\end{array}$ & $\begin{array}{c}r_{6}, \\
\text { people }\end{array}$ \\
\hline 2009 & 7.03 & 4.04 & 4.26 & 4.32 & 5.29 & 5.69 \\
2010 & 5.30 & 2.96 & 5.18 & 7.73 & 5.85 & 7.95 \\
2011 & 27.55 & 3.06 & 5.34 & 4.39 & 6.90 & 1.50 \\
2012 & 29.79 & 2.03 & 3.88 & 0.99 & 2.11 & 1.48 \\
2013 & 28.82 & 2.13 & 3.45 & 1.80 & 2.60 & 1.42 \\
2014 & 22.98 & 1.56 & 5.66 & 1.96 & 3.15 & 1.40 \\
2015 & 12.16 & 2.55 & 8.10 & 2.33 & 6.55 & 3.05 \\
2017 & 10.94 & 2.05 & 7.60 & 3.38 & 33.18 & 3.30 \\
2019 & 11.84 & 1.38 & 4.45 & 3.32 & 14.50 & 2.92 \\
\hline
\end{tabular}

Table 8. Determining the dimensionless type of innovative development indicators of the region's industrial complex

\begin{tabular}{ccccccc}
\hline Year & $y_{r_{1}}$ & $y_{r_{2}}$ & $y_{r_{3}}$ & $y_{r_{4}}$ & $y_{r_{5}}$ & $y_{r_{6}}$ \\
\hline 2009 & 0.55 & 1.04 & 2.24 & 3.22 & 0.94 & 2.65 \\
2010 & 0.38 & 0.94 & 3.15 & 5.53 & 1.06 & 4.07 \\
2011 & 1.71 & 0.81 & 3.05 & 3.23 & 0.89 & 0.98 \\
2012 & 1.71 & 0.78 & 2.00 & 0.80 & 0.32 & 0.93 \\
2013 & 1.72 & 0.80 & 1.89 & 1.96 & 0.47 & 0.91 \\
2014 & 1.43 & 0.85 & 2.49 & 1.81 & 0.66 & 0.98 \\
2015 & 0.76 & 1.96 & 4.16 & 3.08 & 0.76 & 2.41 \\
2017 & 0.81 & 3.01 & 2.14 & 1.24 & 2.45 & 1.17 \\
2019 & 0.81 & 1.19 & 1.42 & 0.98 & 0.70 & 1.07 \\
\hline
\end{tabular}

The natural values of enterprises' innovative activity indicators in the region are determined on the basis of enterprises' quantitative characteristics. For example, the indicator $r_{1}$ (share of IAE) is the ratio of the number of innovatively active enterprises to the total number of surveyed 
Table 9. Calculation of partial functions due to years

\begin{tabular}{ccccccc}
\hline Year & $d_{r_{1}}$ & $d_{r_{2}}$ & $d_{r_{3}}$ & $d_{r_{4}}$ & $d_{r_{5}}$ & $y_{r_{6}}$ \\
\hline 2009 & 0.56 & 0.70 & 0.90 & 0.96 & 0.68 & 0.93 \\
2010 & 0.51 & 0.68 & 0.96 & 1.00 & 0.71 & 0.98 \\
2011 & 0.83 & 0.64 & 0.95 & 0.96 & 0.66 & 0.69 \\
2012 & 0.83 & 0.63 & 0.87 & 0.64 & 0.49 & 0.67 \\
2013 & 0.84 & 0.64 & 0.86 & 0.87 & 0.53 & 0.67 \\
2014 & 0.79 & 0.65 & 0.92 & 0.85 & 0.60 & 0.69 \\
2015 & 0.63 & 0.87 & 0.98 & 0.95 & 0.63 & 0.91 \\
2017 & 0.64 & 0.95 & 0.89 & 0.75 & 0.92 & 0.73 \\
2019 & 0.64 & 0.74 & 0.79 & 0.69 & 0.61 & 0.71 \\
\hline
\end{tabular}

Table 10. Determining the dimensionless type of innovative development indicators of Ukraine's industrial complex for 2009-2019

\begin{tabular}{ccccccc}
\hline Year & $y_{r_{1}}$ & $y_{r_{2}}$ & $y_{r_{3}}$ & $y_{r_{4}}$ & $y_{r_{5}}$ & $y_{r_{6}}$ \\
\hline 2009 & 0.84 & 1.66 & 0.86 & 0.85 & 0.64 & 1.14 \\
2010 & 0.90 & 1.35 & 0.74 & 0.89 & 0.63 & 1.03 \\
2011 & 1.06 & 1.62 & 0.79 & 0.86 & 0.89 & 0.81 \\
2012 & 1.14 & 1.10 & 0.87 & 0.79 & 0.75 & 0.84 \\
2013 & 1.10 & 1.13 & 0.82 & 0.58 & 0.64 & 0.82 \\
2014 & 1.05 & 0.79 & 1.03 & 0.69 & 0.55 & 0.75 \\
2015 & 1.05 & 0.55 & 0.88 & 0.48 & 0.98 & 0.67 \\
2017 & 0.89 & 0.29 & 1.60 & 1.73 & 1.55 & 1.49 \\
2019 & 0.96 & 0.50 & 1.41 & 2.14 & 2.37 & 1.44 \\
\hline
\end{tabular}

Table 11. Calculation of partial functions due to years

\begin{tabular}{ccccccc}
\hline Year & $d_{r_{1}}$ & $d_{r_{2}}$ & $d_{r_{3}}$ & $d_{r_{4}}$ & $d_{r_{5}}$ & $y_{r_{6}}$ \\
\hline 2009 & 0.65 & 0.83 & 0.65 & 0.65 & 0.59 & 0.73 \\
2010 & 0.67 & 0.77 & 0.62 & 0.66 & 0.59 & 0.70 \\
2011 & 0.71 & 0.82 & 0.63 & 0.65 & 0.66 & 0.64 \\
2012 & 0.73 & 0.72 & 0.66 & 0.63 & 0.62 & 0.65 \\
2013 & 0.72 & 0.72 & 0.65 & 0.87 & 0.59 & 0.64 \\
2014 & 0.71 & 0.63 & 0.70 & 0.85 & 0.56 & 0.62 \\
2015 & 0.71 & 0.56 & 0.66 & 0.95 & 0.69 & 0.60 \\
2017 & 0.66 & 0.47 & 0.82 & 0.75 & 0.81 & 0.80 \\
2019 & 0.68 & 0.54 & 0.78 & 0.69 & 0.91 & 0.79 \\
\hline
\end{tabular}

enterprises, it is measured in \% (2):

$$
r_{1}=\frac{N_{i a}}{N} \cdot 100 \%
$$

The average value of innovative costs $r_{5}$ is the ratio of the total number of innovation costs to the number of innovatively active enterprises (3),

$$
r_{5}=\frac{D_{o b}}{N_{i a}}
$$

It is measured in monetary units (UAH thous.) (table 7).

In order to use an integrated efficiency indicator (in the work - the geometric mean), it is essential for the indicators used to have the same units of measurement. Therefore, the transition from natural values of enterprises' innovative activity indicators in the region to dimensionless. Each indicator refers to a similar one calculated for this period for Ukraine as a whole (4), (table 8):

$$
y_{r_{1}}=\frac{\text { region's }^{\prime}}{\text { Ukraine }^{\prime} s} \text {. }
$$

Table 12 provides the results of calculating the comprehensive indicator of innovative development of Zaporizhzhia region's and Ukraine's industrial complexes in 2009-2019.

Table 12. Integral indicators of innovative development of

\begin{tabular}{|c|c|c|c|c|}
\hline \multirow{3}{*}{ Year } & \multicolumn{4}{|c|}{$\begin{array}{c}\text { Integral indicators of enterprises' innovative } \\
\text { development }\end{array}$} \\
\hline & \multicolumn{2}{|c|}{$\begin{array}{l}\text { Zaporizhzhia } \\
\text { region's industrial } \\
\text { complex }\end{array}$} & \multicolumn{2}{|c|}{$\begin{array}{l}\text { Ukraine's industrial } \\
\text { complex }\end{array}$} \\
\hline & $\operatorname{In} x$ & $\begin{array}{l}\text { Changes } \\
\text { to the } \\
\text { previous } \\
\text { year }\end{array}$ & Inn & $\begin{array}{l}\text { Changes } \\
\text { to the } \\
\text { previous } \\
\text { year }\end{array}$ \\
\hline 2009 & 0.77 & - & 0.68 & - \\
\hline 2010 & 0.78 & 0.01 & 0.77 & -0.01 \\
\hline 2011 & 0.78 & 0 & 0.68 & 0.01 \\
\hline 2012 & 0.68 & -0.10 & 0.67 & -0.01 \\
\hline 2013 & 0.72 & 0.04 & 0.65 & -0.02 \\
\hline 2014 & 0.74 & 0.02 & 0.64 & -0.01 \\
\hline 2015 & 0.81 & 0.07 & 0.62 & -0.02 \\
\hline 2017 & 0.81 & 0 & 0.72 & 0.10 \\
\hline 2019 & 0.69 & -0.12 & 0.76 & 0.04 \\
\hline
\end{tabular}
Zaporizhzhia region's industrial complex and Ukraine's industrial complex in 2009-2019

According to the results of data analysis (table 12), it turns out that the integral indicators for assessing the innovative development of Zaporizhzhia region's industrial complex during 2009-2019 are unstable, varying from 0.68 to 0.81 .

These indicators prove the "good" ability and readiness of Zaporizhzhia region's industrial complex to carry out effective innovation activities.

In particular, for Ukraine, the integrated indicators of innovative development of the industrial complex vary from 0.62 to 0.77 . It was found that the indicator of innovative development of Zaporizhzhia region's industrial complex in 2019 is $9.2 \%$ less than Ukraine's industrial complex. This indicates that the innovative development of Zaporizhzhia region's industrial complex lags behind Ukraine's one.

Among the factors favorable for embodying the region's innovation potential, there should be noted the high potential of the region's enterprises to innovate, as well as the relatively high level of R\&D expenditures. The most problematic factors in the region's innovative development are the quality of research institutions and the low correlation of foreign direct investment with new technologies transfer.

The assessment of the enterprises' innovative development in Zaporizhzhia region's industrial complex indicates the need to intensify innovation and optimize innovation potential. In order to further develop the region's indus- 
trial complex, it is necessary to move to its innovative development model. The optimal model of the innovation strategy of Zaporizhzhia region's industrial complex is a cluster development strategy [29].

\section{Conclusions}

In order to improve the innovative development management of Zaporizhzhia region's industrial complex, the innovative strategy of the region's industrial complex is substantiated by assessing the enterprises' innovative activity on an integrated indicator, which is a generalized desirability function. It is established that the comprehensive indicator of innovative development of Zaporizhzhia region's industrial complex in 2019 is $9.2 \%$ less than Ukraine's industrial complex. In addition, the volume of sold innovative products in the region in 2019 decreased by $11.4 \%$ compared to 2017. The decrease in the output of innovative products in the region is largely due to innovation costs reduction from UAH $1,393.4 \mathrm{mln}$. to UAH 681.7 mln., or by 2.1 times. This is due to the declining role of the state as a direct investor, the lack of private investors and the low level of innovation and investment infrastructure in Zaporizhzhia region.

It has been found necessary to intensify innovation and transition to an innovative development model. The cluster development strategy is substantiated by the innovation strategy model of Zaporizhzhia region's industrial complex.

\section{References}

[1] A. Granberg, Osnovy regional'noj jekonomiki (Fundamentals of Regional Economics) (GUVShJe, 2000)

[2] S. Ischuk, Promyslovi kompleksy Ukrainy: Naukovi osnovy terytorial'noi orhanizatsii (Industrial complexes of Ukraine: Scientific bases of territorial organization) (Palyvoda A.A., 2003)

[3] A. Marshall, Principles of economics: unabridged eighth edition (Cosimo, Inc., 2009)

[4] M.E. Porter, On competition (Harvard Business Press, 2008)

[5] J. Schumpeter, U. Backhaus, The theory of economic development (Springer, 2003)

[6] O. Prokopenko, O. Kudrina, V. Omelyanenko, CEUR Workshop Proceedings 2105, 258 (2018)

[7] O. Prokopenko, V. Omelyanenko, T. Ponomarenko, O. Olshanska, Periodicals of Engineering and Natural Sciences 7, 752 (2019)

[8] T. Ponomarenko, V. Khudolei, O. Prokopenko, J. Klisinski, Problems and Perspectives in Management 16, 85 (2018)

[9] G. Savitskaya, Methodology of a comprehensive analysis of economic activity (Metodika kompleksnogo analiza hozyaystvennoy deyatelnosti) (INFRA-M, 2007)

[10] Yale Center for Environmental Law \& Policy, Environment performance index. methodology
(2018), https://epi .envirocenter .yale.edu/ 2018-epi-report/methodology

[11] V. Boiko, A. Kwilinski, M. Misiuk, L. Boiko, Economic Annals-XXI 175, 68 (2019)

[12] T. Savchenko, N. Basiurkina, O. Rodina, A. Kwilinski, Manag. Th. St. Rur. Bus. Infr. Dev. 41, 43 (2019)

[13] I. Perevozova, N. Shmygol, D. Tereshchenko, K. Kandahura, O. Katerna, J. Sec. Sust. 9, 139 (2019)

[14] J. Polcyn, S. Stepień, A. Tosovic-Stevanovic, Environmental Governance as an Element of Sustainable Development in the European Union Countries, in 41st International Scientific Conference on Economic and Social Development (2019), Economic and Social Development, pp. 111-121

[15] L. Zavidna, P. Makarenko, G. Chepurda, O. Lyzunova, N. Shmygol, Academy of Strategic Management Journal 18 (2019)

[16] V. Tkachenko, A. Kwilinski, O. Korystin, N. Svyrydiuk, I. Tkachenko, J. Sec. Sust. 8, 379 (2019)

[17] A. Kwilinski, I. Ruzhytskyi, V. Patlachuk, O. Patlachuk, B. Kaminska, Journal of Legal, Ethical and Regulatory Issues 22, 1 (2019)

[18] O. Baklanova, M. Petrova, V. Koval, Ikonomicheski Izsledvania 29, 68 (2020)

[19] N. Shmygol, W. Luczka, O. Trokhymets, D. Pawliszczy, R. Zavgorodniy, E3S Web of Conferences 166, 13005 (2020)

[20] V. Derbentsev, S. Semerikov, O. Serdyuk, V. Solovieva, V. Soloviev, E3S Web of Conferences 166 (2020)

[21] A. Lobanova, V. Bayura, Y. Viznytsia, L. Bratchenko, V. Karitka, E3S Web of Conferences 166, 10020 (2020)

[22] D. Shiyan, I. Ostapchuk, O. Lakomova, E3S Web of Conferences 166, 01012 (2020)

[23] A. Bielinskyi, I. Khvostina, A. Mamanazarov, A. Matviychuk, S. Semerikov, O. Serdyuk, V. Solovieva, V. Soloviev, IOP Conference Series: Earth and Environmental Science 628, 012019 (2021)

[24] N. Shmygol, O. Cherniavska, T. Pulina, R. Zavgorodniy, Energy Policy Journal 23, 135 (2020)

[25] Official State Statistics Committee of Ukraine, http: //www.ukrstat.gov.ua

[26] Official site of the Main Department of Statistics in Zaporizhzhia region, http: //www . zp . ukrstat. gov.ua//

[27] O. Zhykhor, Kommunal'noe khoziajstvo horodov. Nauchno-tekhnycheskyj sbornyk 73, 56 (2006)

[28] L. Matrosova, Formuvannia orhanizatsijnoekonomichnoho mekhanizmu upravlinnia innovatsijnymy protsesamy u promyslovosti [Formation of organizational and economic mechanism of management of innovative processes in industry] (SUDU, 2000)

[29] T. Pulina, T. But, O. Khrystenko, V. Zaytseva, Lecture Notes in Civil Engineering 73, 709 (2020) 